GOTSKA IEVGENIIA,

Taras Shevchenko National University of Kyiv (Kyiv, Ukraine)

e-mail: ievgeniiagotska@gmail.com,ORCID 0000-0001-5559-0261

\title{
DYNAMICS OF INSTITUTIONALIZATION OF MUSLIM COMMUNITIES IN CRIMEA: JOINING THE CIVIL SOCIETY STRUCTURES
}

The article is devoted to the institutionalization processes within the Muslim communities in the new conditions of political transformations in Ukraine. In the conditions of the annexation of the Autonomous Republic of Crimea, the author sets the goal to investigate the actual ways of joining the structures of civil society, interaction with state authorities and the influence on the religious factor, which, along with the ethnic and national factors, is extremely important for studying in the context of the Crimean Tatars community. The article describes the conditions for the implementation of activities in the framework of migration processes, possibility of a culture development, and the preservation of the identity of representatives of the Muslim communities of the Crimea. Within the framework of this research, work was carried out to find newly created and reorganized organizations and communities, in particular, it was necessary to identify ways to implement the rights to preserve and develop cultural heritage, language, as well as to provide social and legal protection to certain citizens affected by occupation of the peninsula. The results of the study indicate attempts to overcome the isolation policy and obstacles to the adaptation of settlers in a new place, internally migrated persons, as well as an important area of activity was the elimination of the trend of separation of the Caucus Tatar community in Ukraine and its isolation character. In particular, to date, new centers have been created in Ukraine, along with those that have undergone reorganization changes: SDMC public organization "Ixsan-Sincerity" in the city of Drohobych, the Islamic cultural center named after Muhammad Asad in Lviv, the diaspora of the Crimean Tatars has about 10 thousand people in the Kherson region, while there is a rather close living of the Crimean Tatars in the village New Dam in the Vinnytsya region. There is "Crimean Tatars' "Zemlyatstvo (association of people coming from the same area)"" - a public organization representing the interests of the indigenous people of Crimea. So, the main areas of internal migration were Lviv, Vinnytsya and Kherson regions, whose work set the goal of preservation of ethnic and religious identity of the indigenous people of Crimea.

Key words: Islam in Ukraine; Crimea; Muslim community; organization; Spiritual Directorate of Muslims of the Crimea.

\section{Introduction}

The events that took place in 2014 in Ukraine completely changed our state. The state of religious affairs also undergone transformations, we directly were witnesses of some of them, but most of the religious changes were not possible to notice. Today it is necessary to make great efforts to clearly indicate the actual events in the social and religious areas of Ukrainian reality in 2019 , among such themes is the growing influence of the Islamic factor on the domestic political life and on the foreign policy of the country. This is largely due to the migration of the Crimean Tatar people to the territory of mainland Ukraine from the beginning of the annexation of the peninsula by the Russian Federation. There are many reasons and circumstances that caused migration processes, for example certain number of restrictions: freedom of word and freedom of meetings, restriction of language, culture and religy freedoms. And also reasons that directly threatened life: the detection of the deaths of Crimean Tatars with signs of torture, arrests of activists and their missing. For example, during the three months of 2018, 28 activists were arrested in Crimea, and 67 were behind bars. For quite a long time, relations with Islam in Ukraine have been built exclusively on the separation model, which really negatively affected the inter-confessional relations, first of all in the Crimea. It is interestingly that even with the traditionalism of Islam for Ukraine, along with Orthodoxy, relations between the state and Islam were not regulated and devoid of a coherent concept of cooperation. According to Razumkov Center study of 2008 , there is a significant number of those who consider themselves believers but not referring to any of the denominations $-36.9 \%$. While among the adult population of Crimea, individuals who identified themselves with a certain denomination make up less than a third (31\%). Among those who identify themselves with a certain denomination, almost $49.8 \%$ of them attributed themselves to the UOC, $15.4 \%$ to followers of Islam, and $11 \%$ to the UOC-KP. Almost one in ten $(9.8 \%$ of the polled) said that it belongs to other denominations and churches; $86.6 \%$ of the same group of Crimean Tatars consider themselves followers of Islam. It should be borne in mind that according to this sociological survey, the relative majority of Crimeans $(25.8 \%)$ think that the main reason for ethnic conflicts is the incompetence of the 
Ukrainian authorities regarding the international problems of the Crimea (International and interdenomination relations in Crimea ..., 2008). The new realities of the development of the confessional life of Ukraine necessitate the development of a new model of interaction between the state and religious organizations.

The decision of the Verkhovna Rada of Ukraine immediately after the Russian Federation's formal announcement that the Republic of Crimea and city of Sevastopol became subjects of the Russian Federation on March 18 was quite indicative, and resolutions were passed on the guarantee of the rights of the Crimean Tatar people as part of the Ukrainian state. According to the resolution, the Council guarantees "protection and exercising of the inalienable right to self-determination of the Crimean Tatar people" also recognizes Kurultai as the supreme representative body, and sets the task for the Cabinet of Ministers to create "practical mechanisms of interaction between the executive authorities of Ukraine and the Mejlis of the Crimean Tatar people". In this regard, the Verkhovna Rada of Ukraine adopted the Law of Ukraine "On ensuring the rights and freedoms of citizens and legal regime in the temporarily occupied territory of Ukraine" on April 15, 2014, in which "the basis of the humanitarian, social and economic policy of the Ukrainian state in relation to the population of the temporarily occupied territory of Ukraine is the protection and full realization of nationalcultural, social and political rights of Ukrainian citizens, including indigenous peoples and national minorities"1.

The purpose of this study is: to trace the dynamics of institutionalization of the Muslim communities of the Crimea and the ways of their joining the structures of civil society. Having established real conditions, ways of integration into existing religious centers, public and political organizations involved in the Islamic discourse of Ukraine. Having analyzed also the state of social and legal protection of certain public organizations, to offer conditions for peaceful and productive coexistence. According to the report "Islam and civil society in times of trial", there were registered about 400,000 Muslims, and there were 624 registered Muslim communities as of January 1, 2014, and 265 religious organizations of Muslims (Data from Department of Religion ..., 2019) were functioning on the religious map of Ukrain as of January 2019 according to the report "Religious organizations of Ukrain", where the Spiritual Directorate of Muslims of the Crimean Autonomous Republic is represented by six religious communities, and the Spiritual Directorate of Muslims of Crimea - by five communities, the Spiritual Center of Muslims of Crimea has $2 \mathrm{com}$ munities. However, independent communities are also actively represented, there are seventy-five of them. The Muslim community itself has no supreme authority, religious communities are self-regulating and do not depend on the state and other communities in their activities. So, the aim is to investigate the positions of the Crimean Tatars who are struggling to recognize their rights as indigenous people in the context of incorporation of Islam into local cultural and social contexts.

1 Pro Zayavu Verkhovnoyi Rady Ukrayiny shchodo harantiyi prav krymskotatarskoho narodu u skladi Ukrayinskoyi Derzhavy (Dokument № 1140-18). Vidomosti Verkhovnoyi Rady (VVR), 2014, № 15, st. 581. Retrieved from https://zakon3.rada.gov.ua/ laws/show/1140-18

\section{Methodology}

Analysis of the dynamics of institutionalization processes among the Muslim communities of the Crimea needs an understanding of the circumstances that occurred on the peninsula in the past, establishing a link between the political and religious components of the Muslim communities. Therefore, for this study, we used the statistical data of Ukrainian sociological centers, directly relevant resources, pages, official websites, and chronicles of social networks of religious organizations, as well as the work of well-known domestic scholars and scholars of contemporary Islam in Ukraine. Issues of Islam and the forms of its institutionalization are being actively studied by Ukrainian researchers, in particular the position of Islam in Ukraine is studied by well-known religious scholars who offer to consider modern processes in the Muslim world of Ukraine. Issues of Islam and the forms of its institutionalization are actively studied by Ukrainian researchers, in particular renowned religious scholars study Islam in Ukraine and offer a glance at modern processes in the Muslim world of Ukraine, such as the work of A. Kolodny, L. Filippovich, O. Sagan, O. Yarosh, representing the Institute philosophy named after GS Skovoroda of the National Academy of Sciences of Ukraine. Scientists have made a significant contribution to the study of the Muslim community in Ukraine: Yakubovich M. (2016), Brylov D. (2018), Kyrushko M. (2005) and Kozlovskyy I. (2010). Зокрема проблема ісламу в Криму розкривається у напрацюваннях дослідниць Khazir - ohly T. (2010), Muratova E. (2008) та Boyzova O. (2004), where the authors view the phenomenon of Islamic identity with in the framework of a specific region - the Autonomous Republic of Crimea. However, in our opinion, the role of the Islamic factor in the period of active geopolitical changes in the state is not sufficiently studied, while the transformational processes in the Muslim environment continue and far from its completion.

\section{Results and Discussion}

Crimean Tatars are indigenous inhabitants of Crimea and has the largest Muslim community in Ukraine. Moreover, the path of Islam in Ukraine starts with the history of the Crimean Tatars. Islam came to Crimea with Muslim traders and Sufi missionaries from Asia Minor in the ninth to eleventh centuries. By the end of the eighteenth century here were about 1,600 mosques, 25 madrasas and a lot of mektebes in Crimea. By 1914, there were only 729 mosques left in Crimea, when the Soviet authorities came Islam was destroyed in the Crimea: about 200,000 people were deported from their homeland. Residents of the Crimea returned home after Ukraine became independent, which led to new challenges and problems in the sphere of state and inter-confessional issues. However, in the period when Crimean Tatars returned to the peninsula, the Muslims consolidated. First of all, this is evidenced by the fact that a network of Muslim communities was created, and secondly, new mosques destroyed by the previous authorities were created. In 2007, were communities were were subordinate to the Crimean's Muftiyat and autonomous communities, with a total - of 380 communities. Immediately after the annexation of Crimea, the situation has changed, we seek to trace the peculiarities of the community integration in the new Crimean reality.

The Muslim community counted in the Crimea about 245 thousand people, half of the entire Muslim community of Ukraine was concentrated on the peninsula. However, 
the emergence of radical religious groups of Salafites and Habashites shows that the religious factor was too closely associated with national ideology. Most Muslims in the Crimea represented Islam exclusively as fragments of ethnic and national identity. Tavria National University name V. I. Vernadsky conducted a study in 2008 "Crimean Muslims: Who Are We Who?" Respondents answered questions about their religious and identity priorities. Almost $80 \%$ of the respondents said they consider themselves Muslims precisely because of the historical and cultural traditions of their people. So to the question "Is Ukraine sufficiently guaranteed the rights and freedoms of Muslims and the equality of all religions before the law"? and only $24.3 \%$ agreed to this. The conclusions of this study identified the majority of Crimean Tatars as Muslims, but the widespread attitude towards Islam focuses attention on the cultural aspect, which represents the authentic tradition of the Crimean Tatars. The central idea that historic events pour into the spiritual sphere of life of the Crimean Tatar people in the poll "The Past, Present and Future of the Crimean Tatars in the Discourse of the Muslim Community of Crimea" , which was held within the framework of the Crimean Political Dialogue project Kut N. and Y. Muratova in 2011. This is extremely negative, because in connection with the deportation of Crimean Tatars in 1944. Muslims have lost a large number of Imams, religiously educated people, which, it can be assumed, led to the destruction of the spiritual heritage, and the Muslim Umma degraded. According to respondents, the deportation and annexation of the Crimea have had a significant impact on the self-identification of the Crimean Tatars, respondents said.However, as we noted earlier, powerful religious and cultural centers have been operating in the Crimea, we have already mentioned one of them - The Spiritual Direction of the Muslims of Crimea SDMC. In 2018, data from the religious network indicated that SDMC was directed by 341 Muslim communities, in which 5 spiritual educational institutions were active, 217 people were taught there, and 361 religious figures. Most of the religious organizations of the SDMC were exactly in the Crimea and were represented exclusively by the Crimean Tatars, also their identity was laid in the organizations work. To a certain extent, it was an isolated factor that divaded Muslims in one country much more than ideological and dogmatic differences in the interpretation of Islamic doctrine. An interesting fact is that SDMC was the only spiritual center of Ukraine that conducted the Mufti rotation. While the policy of the ARC's municipal authorities was selective and focused solely on the needs of the denomination, which undoubtedly contributed to inter-confessional conflicts, and bodies of state authority of Ukraine didn't regulate them. Considering a number of problems in the Muslim Crimean environment, the events of 2014 are becoming more apparent to us. From the very beginning of the conflict, SDMC expressed its negative attitude to the policy of the occupiers, but later changed its ideological preferences and accepted the terms of cooperation with the Muslims of the Russian Federation. The Russian Mufti Council visited Crimea one of the first, spoke out loud speeches and initiated the re-registration of the SDMC in the Spiritual Directorate of Muslims of the Crimea and Sevastopol (SDMC'S).

Emirali Ablaiev remained the mufti of the Muslims of Crimea, and then the excluded from the All-Ukrainian Council of Churches and Religious Organizations, however, remained a member of the Mejlis for some time.
Crimean Tatars in mainland Ukraine did not have a representative in the All-Ukrainian Council of Churches and Religious Organizations, unfortunately this fact demonstrated the state of state-confessional relations in the country. Religious network of Crimea was geared towards rapprochement in cooperation with the Russian Federation in the following circumstances: Teachers from Turkey left schools and madrasas. Consequently, SDMCiS became one of the Muftiates of the Russian Federation, limited the interference of international organizations in its activities. The management was on the way of displacement of any alternative Muslim movements from the peninsula. Also, SDMC'S started a struggle against the Majlis, destroying the system that was built earlier, where the national and religious movement went alongside. In 2016, the Crimean authorities called Mejlis, the "highest representative representative body of the Crimean Tatar people", an "extremist organization", and the dialogue between the Mejlis and the new government in the Crimea has stopped because of a series of conflicts. One of such conflicts was the desire to create a new "Muftiat of Crimea" in mainland Ukraine. According to the "Regulation on the Mejlis of the Crimean Tatar people", the Mejlis declared the goal "to restore the national and political rights of the Crimean Tatar's and to realize the rights of free nationalstate self-determination on its national territory".

The revival of language, culture and religion, the adoption of social programs, care for the poor and the environment, while remaining a secular public organization - these are the back grounds that were always secured by the structure of the Mejlis. However, the Majlis leadership, Mustafa Jemeiliev and Refat Chubarov, controlled religious affairs, the activities of Muslim communities, the emergence of new communities and the settlement of conflicts in the Crimea.According to E. Muratov, "Despite formal independence, the SDMC fully agrees with the Mejlis of the Crimean Tatar's, headed by Mustafa Dzhemilev. The Institute of the Special Representative of the Majlis in the Muftiyat plays a key role, which largely determines the religious policy through consultations with the Majlis leadership" (Muratova, 2008). And another consequence of the events of 2014 was the problem of the adaptation of immigrants and internally displaced persons, and the state and constitutional law guarantee freedom of conscience.

As of 2016 in Ukraine there are 15 to 25 thousand settlers - Crimean Tatars according to rough estimates of KrymSOS organization. KrymSOS is engaged in refugee affairs since 2014, draws the attention of the United Nations to the violation of human rights in the Crimea and tries to engage in international support. It is known that the main areas of internal migration were Kherson, Lviv and Vinnitsa regions, where, in turn, ethno-religious communities were created. As M. Yakubovich notes: "Confessional identity also worked in choosing a place for migration - the followers of Hizb ut-Tahrir mainly settled on Lviv region, Salafites in Vinnitsa region and Kyiv region; Muslim secular or "traditional Hanafite-maturidite orientation moved to Kherson region or to the city of Kiev" (Yakubovych, 2016: 60).

In the city of Drohobych, different communities live and operate: Ukrainians, Poles, Jews, Romans, Belarusians, and henceforth Crimean Tatars. In the spring of 2014, five families moved there, now about a hundred Crimean Tatars live there.

Ukrainian Greek Catholic Church (UGCC) Drohobych Eparchy "Caritas" immediately accepted them and helped to adapt to the new environment, lifestyle and local culture 
for a long time. Interestingly, the scarce representatives of other nationalities live in such a small place; the adepts of Islam are Azerbaijani and Uzbeks.In Drohobych, the Crimean Tatars began to join the initiative group, later it became a public organization - "Ihsan-Sincerity". They take part in various international projects, carry out activities, receive grants and actively interact with local residents within their activities. A festival of Crimean Tatar culture was organized in Drohobych, where seminars and trainings were held with the participation of Kyiv specialists. Also, the exhibition "Drohobych in the Crimea" contributed to the consolidation of society, where locals who visited Crimea at one time were able to experience their impressions and photos. Already in October 2018 in Drohobych, the cultural center of Crimean Tatars was opened. The media covered an important event for the community. For example, the head of the "Ihsan-Sincerity" foundation Rustem Yakubov noted that "The premises of the center were received in 2016, it was in poor condition, but its convenient location, size, infrastructure, number of rooms, and others were arranged. The community didn't have the money to repair, and we turned to potential sponsors. As a result, a financial grant was received for the repair and purchase of equipment from the Ministry of Foreign Affairs of the Republic of Poland"2. The main tasks of the institution of this type are preservation of the language, culture and traditions of the Crimean Tatar community. The Center also appeared as an information platform for eliminating stereotypes and organized the cooperation between the Crimean Tatar community and the inhabitants of the city of Drohobych. The head of "IhsanSincerity" said: "We would like these differences that exist in our cultures not to prevent us from living together in the city of Drohobych. Therefore, we are always glad to receive guests in our center, which was equipped by all of our community and with the support of our friends" 3 . Currently, when the activity of "Ihsan-Sincerity" is analyzed and the page is being revisited in Facebook, we are watching an active public activity aimed at dialogue and paying attention to the Crimean issue. Activists regularly invite 1) journalists for dialogue, 2) OSCE representatives with proposals to local authorities 3) organize intercultural encounters with women, where family values and recommendations for the upbringing of children are discussed.

Vinnytsya Region is another example of the close living of the Crimean Tatar community: many Salafists-Crimean Tatars began a new life in the village of Nova Hriblja. Crimean Tatars settled after the annexation of Crimea by a whole community at a local hostel. It should be noted that Nova Hreblya received serious international financial assistance through forced migrants from the Crimea, which became much more. The Office of the United Nations High Commissioner for Refugees provided funds for the development of local infrastructure. Also, thanks to the funds of American partners, the dormitory in which settlers settled the functioning of the kindergarten. Approximately 35 thousand people left the Crimean peninsula, approximately half were Crimean Tatars who migrated throughout Ukraine, some were in the capital, a large number in the western part of Ukraine, in Lviv, Ivano-Frankivsk, Ternopil

\footnotetext{
2 U Drohobychi vidkryly kulturnyy tsentr krymskykh tatar. Retrieved from https://zik.ua/news/2018/10/18/u_drogobychi_vidkryly_kulturnyy_tsentr_krymskyh_tatar_1429257.

3 Krymskotatarska hromada Drohobycha "Ikhsan-Shchyrist". Retrieved from: https://www.facebook.com/drohobych.krym/.
}

and a certain part in Kherson, where 7 to 8 thousand Crimean Tatars lived to the annexation of the Crimea. The creation of its own Muftiyat was a necessity, "the Crimean Tatars' communities, together with other Muslim communities, have taken the initiative to create a spiritual management of the Muslims of the Crimean Tatars of Ukraine in order for the Muslim community to develop more effectively". It was succeeded. On November 19, 2016, representatives of 14 religious Crimean Tatar communities created the Muftiat at the congress in Kyiv. Ayder Rustamov was elected Mufti, who heads the Committee of Spiritual Values of Muslims under the rule of the Crimean Tatars' Landownership in Kyiv. The participants of the constitution formed the Council of Uleams (scientists with knowledge of religion), the president of the Association of Muslims of Ukraine Suleiman Khairullaev headed her $^{4}$.

The Department of Nationalities and Religions of the Ministry of Culture of Ukraine refused to register for a long time the Spiritual Directorate of Muslims of Crimea SDMC in Kyiv, because its statute required finalization and correction. Changes in legislation also led to religious organizations re-registering to maintain their status. As early as October 2017, the Department of Nationalities and Religions of the Ministry of Culture of Ukraine registered the Spiritual Directorate of Muslims of the Autonomous Republic of Crimea, headed by A. Rustemov, commenting as follows: "Religious communities are in Kherson, Vinnitsa, Lviv, and we decided to create a single structure that would consolidated all communities and worked in one direction". The strategic goals of the organization are indicated on the official website of the Spiritual Directorate of Muslims of Crimea: promoting the development of the Muslim community, promoting interconfessional dialogue, promoting civic engagement and promoting a better understanding of Islam. Within the framework of its activities, SDMC started cooperation with the Department of Religious Affairs of Turkey - Diaanet, working together on charitable projects. It is also worthwhile recalling the organization of Hajj for 26 people from Ukraine.

On May 16, 2017, the Crimean Tatar Muslim community of Lviv has already opened its own cultural center named after Muhammad Asad with the support of the Spiritual Office of Muslims of the Autonomous Republic of Crimea. This institution, acting as the official representation of a national institution in western Ukraine, also acts as a platform for the development of the local Muslim community, promoting inter-confessional dialogue, enhancing civic activity and promoting a better understanding of Islam among the local community.

Educational programs were implemented on the basis of the institution, for the support of NGOs; various social and cultural events took place, projects involving active youth and women's initiatives were implemented, as well as constant reception of citizens for various adaptation questions at the new place of residence. The adjustment of the connection with the Crimea and the support of the Crimean Tatars who are under the rule of the undemocratic regime established in 2014 is the central direction of the activity of the cultural center. In Crimea, the Crimean Tatar community held a number of events dedicated to the Day

\footnotetext{
${ }^{4}$ Minkultury Ukrayiny ne zareyestruvav ustav krymskotatarskoho muftiyatu. Retrieved from https://religions. unian.net/state/1843936minkulturyi-ukrainyi-ne-zaregistrirovalo-ustav-kryimskotatarskogomuftiyata.html.
} 
of resistance of the Crimean occupation: Silent protest action "Free Crimea!" Within the framework of the international movement "Liberatecrimea" with the participation of settlers and representatives of local public organizations, a joint prayer service of the representatives of the Muslim community in memory about the victims of political repressions in Crimea, a photo exhibition devoted to Crimean political prisoners, a panel discussion with the participation of political scientists and public figures, a film show of a documentary film on resistance in the occupation - "When the wind lull". The Crimean Tatar delegation headed by one of the leaders of the Crimean Tatar national movement Mustafa Dzhemilev met with Deputy Mayor for Development Andriy Moskalenko, who discussed opportunities for deepening cooperation, as well as various topics related to the activities of the Crimean Tatar community in Lviv. They noted that they are now particularly interested in establishing cooperation with local universities, in particular - to attract as many students from Crimea to the city as possible. As part of the discussion, it was also said that about 200 young community members are studying in Lviv, but this is not a limit, as there is a huge educational potential here.The Mufti of the Crimean Tatars in mainland Ukraine, Aider Rustamov, heads the Committee for the Spiritual Values of Muslims under the rule of the Crimean Tatars of the Crimean Tatars. "Crimean Tatars community" is a public organization representing the interests of the indigenous people of Crimea living in Kyiv, Aslan Umerov - the head of the board. They ensure the rights and freedoms of the Crimean Tatars by their activities. The organization's activities are aimed at preserving the spiritual and cultural heritage of the Crimean Tatars, mostly outside their historical location in the framework of their activities, "Crimean Tatars community" acts as the organizer of exhibitions of Crimean Tatar art. The demonstration of decorative and applied art was in the museum of Ivan Gonchar in Kiev, there were represented: ceramic panels and wall plates, batik-panels, pottery dishes, glass painting, wood carvings, coffee tables, jewelry, silver filigree, silk embroidery, gold embroidery, plastic of small forms, figures of people in folk costumes and even traditional toys.

The main objectives of the community are: 1) consolidation of the Crimean Tatar people in Ukraine; 2) dialogue with representatives of other nationalities, living in the same territory, and usually 3 ) ensuring the rights and freedoms of the Crimean Tatar ${ }^{5}$. Committees work actively, among them: cultural development, external relations, social development, education and personnel strategies, spiritual values, media and information. The charitable foundation exists within the organization "EVCAF Ukraine", the main activities are "the realization and protection of human rights and fundamental freedoms of Ukrainian people, including the Autonomous Republic of Crimea and the city of Sevastopol, through the promotion of the practical implementation of the provisions of the current normative legal acts of Ukraine and the international treaties of Ukraine, the consent to be bound by the Verkhovna Rada of Ukraine, as well as all other commitments of Ukraine in the field of human rights and fundamental freedoms ${ }^{6}$. Public organizations are represented in Kyiv, Lviv, Dnipropetrovsk, Kherson and Genichesk. Continuing the theme

\footnotetext{
5 Public organization "Zemlyatstvo krymskykh tatar". Retrieved from http://qirimcemiyeti.org/. 6 Ibid.
}

of Crimean Tatar communities in Kyiv, it is necessary to indicate another platform for the implementation of social and cultural processes - the state enterprise "Crimean House". It was organized in 2015 , the main goal was defined - control and observance of the rights and freedoms of Ukrainian citizens. National minorities and indigenous peoples in the temporarily occupied territories of Ukraine were also taken into consideration. At the Crimean House from time to time organize public discussions, press conferences, days of speech and memory, even sports competitions and film shows. All of these actions are aimed at maintaining cultural traditions, such as the "Amazing Stories of the Crimea", which took place in February 2019 in the capital's Artistic Arsenal, - the exposition consisted of Scythian gold ornaments, patterns of weapons and dishes of different periods, paintings and other artifacts.

The event was organized with the support of the Ministry of Information Policy of Ukraine, as well as the V International Forum "Occupied Crimea: 5 Years of Resistance", was held in parallel where in the panel discussion leading experts and leaders of public opinion in Lviv region discussed the state of affairs on the annexed peninsula. On February 28, 2019, in the Cultural Center of the Crimean Tatars in Lviv, in the framework of the discussion, certain negative tendencies in the general attitude of the public opinion about the prospects of de-occupation and reintegration of temporarily uncontrolled territories of Ukraine were reported. Such conclusions were made on the basis of monitoring of social networks and observations.

The published idea was promulgated: "correction of the historical error - the constitutional consolidation of the right of the indigenous people of Crimea to self-determination by changing the status of the peninsula and creating the national-territorial autonomy of the Crimean Tatars". The implementation of social and legal protection of migrants was also an important and prominent topic. "So far, some legislative norms have not been changed to new realities and directly discriminate against the rights of displaced persons. For example, the restriction of the right to elect and be elected to local authorities". It should also be noted that on February 26, 2019, on the day of the fifth anniversary of the occupation of Crimea, a flashmob was held in Kherson on the Day of Crimean resistance to Russian occupation, organized by the Kherson City Mejlis of the Crimean Tatar people. In general, in the Kherson region, the diaspora of Crimean Tatars has about 10 thousand people, and even the villages have the opportunity to study the Crimean Tatar language. Most Crimean Tatars live in the Henichesk district of the Kherson region. In the Genichesk region, the Crimean Tatar community is about 13 percent of the population, and this is where they plan to build mosques, which are financed by the Crimean Tatar diaspora of Turkey. The mosques will belong to the villages of Partizans and Schaslyvtsev of the Genichesk District, which are not under the control of the State Duma, which also have a room for prayer in this region. In the Kherson region there are 13 communities of the State Duma and one mosque in Kherson ${ }^{7}$. I must say that the Spiritual Directorate of Muslims of Ukraine (SDMU) does not establish cooperation with the Supreme Administrative Court of Ukraine, publicly does not support their integration into

\footnotetext{
U Khersonskiy oblasti pobuduyut mecheti za koshty krymskotatarskoyi diaspory Turechchyny. Retrieved from https://ua.krymr.com/a/news/28350008.html
} 
Ukrainian society. The tense relationship between the two Directorates was always characterized by a change of rise and a decline in tension.

The integration of Crimean Muslims into the sociopolitical life of Ukraine is a rather dynamic process, however, the experts of Islam in Ukraine point to the passive roles of the authorities, which is more ignored than caring for the realization of the rights and freedoms of the Muslim community in the country. While social and political stability should be controlled by the state in the Muslim environment. V. Shved, vice-president of the Ukrainian Center for Islamic Studies, scientific advisor for the Mufti of the Spiritual Directorate of Muslims of Ukraine, Umma, is quoted as saying "working out a model for the integration of the Crimean Tatars in the Ukrainian society, which, on the one hand, would ensure the establishment of an optimal form for the implementation of the Crimean Tatar self-government the people within the bounds of Ukrainian statehood, the realization of its political and legal, socioeconomic and spiritual needs, and on the other - would contribute to the strengthening of interethnic consent and peace on the Crimea to the peninsula (Muratova, 2008: 163).

\section{Conclusions}

Since there is no administrative system in Islam, which is spread in the territory of Ukraine, Muslims are united around religious centers: Spiritual directorates, communities and organizations headed by the mufti or the chairman of the board. The first such religious center became the Spiritual Directorate of Muslims in Crimea in 1991 , which in turn was engaged in what is now expected from the Spiritual Directorate: the construction of mosques, creation of religious communities, social work, upbringing of believers and their education. In our opinion, the main internal problems among the Muslim community of Ukraine, in particular the Crimean Tatar community, is, firstly, the constant rivalry between various socio-political organizations for representation of the interests of the entire community. Secondly, passive participation by the state and the main branches of government that do not promote the consolidation of Muslims in Ukraine and impede the solution of socially important problems for the Muslim community, such as the lack of prayer rooms and cemeteries. These are ones of the reasons that impedes the solution of topical community problems at the local level. This is evidenced at least by the current history of the Crimean Tatar movement, which must adapt to new conditions of its existence and join the structures of civil society. In addition, in spite of the number of current Crimean Tatar organizations in mainland Ukraine, it is too early to talk about a true religious association that is capable of presenting the mood and demands of the entire Crimean Tatar people. It is interesting that all other Muslims in Ukraine are also quite difficult to imagine as the united common organization. However, we would like to suggest ideas over which the Muslim community of Ukraine, and in particular Crimean Tatars, could work together. Firstly, it is to adequately cover the information on the life of the Crimean Tatar community in mainland Ukraine and the establishment of a dialogue within the local community. It also concerns the protection of human rights and minorities, and the respect and control of religious freedoms, in our opinion, this is possible through qualitative education and education. In particular, creation of opportunities for young people to engage in education and study of Islamic traditions and Crimean Tatar culture will serve the future for which an unification is possible. The consolidation of such a level will lead to the institutionalization of the Muslim communities of the Crimea. The need to discuss topical issues and make constructive decisions related to various aspects of the adaptation of internally displaced persons temporarily located on the continent remains obvious. In particular, it is extremely important to promote the preservation of the ethnic and religious identity of the indigenous people of the Crimea - the Crimean Tatars, the realization of the right to preservation and development of the cultural heritage and the native language, as well as to provide social and legal protection to certain citizens affected by the occupation of the Crimea.

\section{REFERENCES}

Bohomolov, O. V. \& Danylov, S. I. \& Semyvolos, I. M. \& Yavorska, H. M. (2005). Islamska identychnist v Ukrayini. Kyiv: AMES. 130 pp. (In Ukrainian)

Boytsova, O. Ye. (2004). Stan musulmanskykh hromad Sevastopolskoho rayonu $v 20-k h$ rr. XX st. Ukrayinske relihiyeznavstvo. № 3-4. Pp. 171-178. (In Ukrainian)

Brylov, Denis (2018). Islam in Ukraine: the language strategies of Ukrainian Muslim communities. Religion, State and Society, 46:2, 156-173, DOI: 10.1080/09637494.2018.1456766

Data from Department of Religion and Nationalities of the Ministry of Culture of Ukraine. Religious organizations in Ukraine (as of January 1, 2019). Retrieved from https://risu.org.ua/ua/ index/resourses/statistics/ukr_2019/75410/

Ishyn, A. \& Bednarskyy, O. \& Shvets, O. (2005). Do pytannya shchodo proyaviv etnopolitychnykh superechnostey $v$ Krymu na suchasnomu etapi. Simferopil: SF NISD, 60 pp. (In Ukrainian)

Khazyr-ohly, T. (2010). "Fikkh menshyn" yak sposib isnuvannya islamu v Yevropi. Ukrayinske relihiyeznavstvo. Special Issue № 1. (In Ukrainian)

Kozlovskyy, I. A. and Lukovenko, I. H. (2010). Dukhovnyy tsentr musulman Ukrayiny. In: Kolodnyy A. (ed.) Istoriya relihiy $v$ Ukrayini u 10 tomakh. Relihiyni menshyny Ukrayiny. Vol. 7. Kyiv, Pp. 536-542. (In Ukrainian)

Kyryushko, M. I. \& Boytsova, O. Ye. (2005). Islam v Krymu: relihiyno-natsionalna samoidentyfikatsiya krymskotatarskoho narodu. Kyiv: Svitohlyad. 300 p. (In Ukrainian)

Mizhnatsionalni ta mizhkonfesiyni vidnosyny v AR Krym - stan, problemy, shlyakhy vyrishennya (2008). Proceeding of Conference "AR Krym siohodni i zavtra: zona ryzyku chy konfliktu?". Kyiv: Tsentr Razumkova. December. P. 5. (In Ukrainian)

Muratova, Elmira (2008). Islam u suchasnomu Krymu: indykatory ta problemy protsesu vidrodzhennya. Symferopil: PE Elinio, 240 pp. (In Ukrainian)

Taran, V. O. (2014). Suchasna Ukrayina ta "islamskyy" faktor. Kulturolohichnyy visnyk Naddniprianschyny. Issue 32. Pp. 94101. Retrieved from http://www.irbis-nbuv.gov.ua/cgi-bin/ irbis_nbuv/cgiirbis_64.exe?I21DBN=LINK\&P21DBN=-UJRN\&$Z 21 \mathrm{ID}=\& S 21 \mathrm{REF}=10 \& S 21 \mathrm{CNR}=20 \& S 21 \mathrm{STN}=1 \& S 21 \mathrm{FMT}=\mathrm{ASP}_{-}-$ meta\&C21COM=S\&2_S21P03=FILA=\&2_S21STR=Kultv_2014_32_20 (In Ukrainian)

Yakubovych, Mykhaylo (2016). Vid Maydanu do ATO: ukrayinski musulmany $v$ umovakh viyskovo-politychnoyi kryzy. Vinnytsya: TOV "Nilan-LTD", 264 p. (In Ukrainian)

\section{LIST OF REFERENCE LINKS}

Brylov Denis. Islam in Ukraine: the language strategies of Ukrainian Muslim communities. Religion, State and Society. 2018. 46:2. Pp. 156-173. DOI: 10.1080/09637494.2018.1456766

Богомолов О. В., Данилов С. І., Семиволос І. М., Яворська Г. М. Ісламська ідентичність в Україні. Київ: AMES, 2005. $130 \mathrm{c}$. 
Бойцова О. Є. Стан мусульманських громад Севастопольського району в 20-х рр. XX ст. Українське релігієзнавcmвo. 2004. № 3-4. C. 171-178.

Дані департаменту у справах релігії та національстей Міністерства культури України. Релігійні організації в Україні (станом на 1 січня 2019 р.) URL: https://risu.org.ua/ua/index/ resourses/statistics/ukr_2019/75410/

Ішин А., Беднарський О., Швець О. До питання щодо проявів етнополітичних суперечностей в Криму на сучасному етапі. Сімферополь, 2005.

Кирюшко М. І., Бойцова О. Є. Іслам в Криму: релігійнонаціональна самоідентифікація кримськотатарського народу. Київ: Світогляд, 2005. 300 с.

Козловський І. А., Луковенко І. Г. Духовний центр мусульман України. Історія релігій в Україні у 10 m. Релігійні меншини України. m. 7. / кол. монографрія за ред. А. Колодного. Київ, 2010. С. 536-542.

Міжнаціональні та міжконфесійні відносини в АР Крим стан, проблеми, шляхи вирішення: робочі матеріали до Фахової дискусії на тему "АР Крим сьогодні і завтра: зона ризику чи конфрлікту?". Київ: Центр Разумкова, 2008, грудень. С. 5.

Муратова Е. Іслам у сучасному Криму: індикатори та проблеми процесу відродження. Симферопіль: ЧП " Ельіньо", 2008. $240 \mathrm{c}$.

Таран В. О. Сучасна Україна та "ісламський" фактор. Культурологічний вісник Наддніпрянщини. 2014. Вип. 32. С. 94-101.

Хазир-огли Т. "Фікх меншин" як спосіб існування ісламу в Європі. Українське релігієзнавство. 2010. Спецвипуск 1.

Якубович М. Від Майдану до АТО: українські мусульмани в умовах військово-політичної кризи. Вінниця: ТОВ "НіланЛТД", 2016. 264 с.

Гоцька Євгенія,

Київський національний університет імені Тараса Шевченка (м. Київ Україна)

e-mail: ievgeniiagotska@gmail.com,ORCID 0000-0001-5559-0261

\section{ДИНАМІКА ІНСТИТУЦІОНАЛІЗАЦІЇМУСУЛЬМАНСЬКИХ ГРОМАД АР КРИМ: ВХОДЖЕННЯ ДО СТРУКТУР ГРОМАДЯНСЬКОГО СУСПІЛЬСТВА}

Стаття присвячена процесам інституціоналізації всередині мусульманських громад за нових умов політичних трансформацій в Україні в умовах анексії АР Крим. Автор ставить за мету дослідити актуальні шляхи входження до структур громадянського суспільства, взаємодію з органами державної влади та вплив релігійного чинника, що поряд з етнічним та національним вкрай важливо для вивчення в контексті кримськотатарської громади. У статті висвітлені умови діяльності громад щодо міграції, розвитку культури та збереження власної ідентичності представників мусульманських громад АР Крим. У рамках цього дослідження було проведено роботу з пошуку новостворених та реорганізованих організацій та громад, зокрема необхідно було виявити шляхи реалізації прав на збереження та розвитку культурної спадщини, мови, а також забезпечення соціально-правового захисту окремих громадян, постраждалих від окупації півострова. Результати дослідження засвідчують спроби подолання ізоляційної політики та перешкод 3 адаптацією переселенців, внутрішньо переміщених осіб, також важливим напрямом діяльності сталало усунення тенденції роз'єднання кримськотатарської громади в Україні та подолання її ізоляційного характеру. Зокрема на сьогоднішній день в Україні були створені нові осередки, поряд 3 тими, що зазнали реорганізаційних змін: ДУМК, громадська організація "Іхсан-Щирість" у м.Дрогобич, ісламський культурний центр імені Мухаммада Асада у Львові. На Херсонщині діаспора кримських татар налічує близько 10 тис. осіб, тоді як на Вінниччині також відзначається досить тісне проживання кримських татар у селі Нова Гребля. Також у столиці існує "Земляцтво кримських татар" - громадська організація, що представляє інтереси корінного народу Криму. Отже, основними напрямками внутрішньої міграції стали Львівська, Вінницька та Херсонська області, в роботу яких закладена мета зберегти етнічну та релігійну ідентичності корінного народу Криму.

Ключові слова: іслам в Україні; Крим; мусульманська громада; організація; ДУМК.

(C) Gotska levgeniia

Надійшла до редакції: 16.05.2019

Прийнята до друку: 10.06.2019 